\title{
PERBEDAAN PENGETAHUAN GIZI DAN KEBUGARAN JASMANI PADA REMAJA YANG OVERWEIGHT DAN NON OVERWEIGHT DI SMK BATIK 2 SURAKARTA
}

\author{
Rahmadhani Nur Hidayanti $^{1}$, Elida Soviana², Endang Nur Widyaningsih ${ }^{3}$ \\ ${ }^{1}$ Rumah Sakit Angkatan Laut Merauke Jl. Trikora No 7, Kelurahan Maro Merauke, \\ Papua 99613. Email: ${ }^{1}$ Rahmadhaninurhidayanti534@ymail.com \\ ${ }^{2,3}$ Program Studi Ilmu Gizi FIK UMS. Jl. A. Yani Tromol Pos I Pabelan Surakarta. \\ Email: ${ }^{2}$ elida.soviana@ums.ac.id, ${ }^{3}$ en239@ums.ac.id
}

\begin{abstract}
ABSTRAK
Overweight merupakan ketidakseimbangan asupan zat gizi. Pola makan remaja saat ini mengarah ke pemilihan bahan makanan cepat saji yang tinggi kalori yang terdiri dari karbohidrat dan lemak. Makanan ini jika dikonsumsi secara berlebihan dapat memicu terjadinya overweight. Penelitian ini bertujuan untuk mengetahui perbedaan pengetahuan gizi dan kebugaran jasmani pada remaja yang overweight dan non overweight di SMK Batik 2 Surakarta. Jenis penelitian yang digunakan dalam penelitian ini yaitu observasional dengan pendekatan cross sectional. Sampel yang digunakan adalah remaja di SMK Batik 2 Surakarta kelas X dan XI yang berstatus gizi overweight dan non overweight dengan masing-masing kelompok berjumlah 30 siswa. Pengambilan data dengan cara simple random sampling. Pengetahuan gizi diperoleh dengan cara pengisian kuesioner sedangkan kebugaran jasmani menggunakan Harvard Step test. Penelitian menunjukkan bahwa sebagian besar baik kelompok overweight dan non overweight memiliki pengetahuan gizi kategori cukup yaitu 53\%. Kebugaran jasmani pada remaja yang overweight sebagian besar memiliki kebugaran jasmani yang kurang yaitu $73 \%$, sedangkan kebugaran jasmani pada remaja yang non overweight sebagian besar memiliki kebugaran jasmani yang cukup yaitu $40 \%$. Tidak terdapat perbedaan pengetahuan gizi pada remaja yang overweight dan non overweight dan terdapat perbedaan kebugaran jasmani pada remaja yang overweight dan non overweight.
\end{abstract}

Kata kunci : pengetahuan gizi, kebugaran jasmani, overweight

\begin{abstract}
Overweight is an imbalance of nutrient intake. Diets of adolescents today lead to the selection of fast food which is high in calories consisting of carbohydrates and fats. These foods if are consumed in excess can lead to overweight. This study aimed to determine differences in nutritional knowledge and physical fitness in adolescents who were overweight and non-overweight at vocational high school of Batik 2 Surakarta. This observational study used cross sectional design. The respondents werestudents at vocational high school of Batik 2 Surakarta grade X and XI which were divided into
\end{abstract}


two group overweight and non-overweight with 30 students in each. Retrieval of respondents by simple random sampling. Nutrition knowledge date were obtained by filling out a questionnaire while physical fitness date were measured using the Harvard Step test. The results showed that most adolescents 53\%had sufficient knowledge about nutrition in each group.Most adolencents who were overweight (73\%) had poor physical fitness, mearwhile those who were nonoverweight had sufficient physical fitness (40\%). There was no difference in nutrition knowledge in adolescents who were overweight and non-overweight but there was difference in physical fitness in adolescents were overweight and non-overweight.

Keywords: knowledge of nutrition, physical fitness, overweight

\section{PENDAHULUAN}

Masa remaja merupakan masa yang rentan terhadap gizi, oleh karena itu remaja perlu mendapatkan perhatian yang khusus. Pertumbuhan pada remaja berlangsung secara cepat, sehingga remaja memerlukan asupan gizi yang seimbang untuk memenuhi kebutuhan di dalam tubuh. Kebutuhan zat gizi berkaitan erat dengan masa pertumbuhan remaja dalam meningkatkan pertumbuhan fisik dan perkembangan yang drastis. Remaja yang asupan gizinya terpenuhi sesuai dengan kebutuhan maka pertumbuhannya akan optimal (Almatsier, 2011). Secara nasional prevalensi overweight pada usia 16-18 tahun yaitu 5,7 \%. Di Jawa Tengah prevalensi overweight yang terjadi pada remaja sebanyak 5,4 \% (Riskesdas, 2013).

Overweight pada remaja terjadi karena ketidakseimbangan asupan zat gizi. Pola makan yang terjadi pada remaja saat ini yaitu pola makan tinggi energi yang sebagian besar terdiri dari karbohidrat dan lemak. Asupan energi yang tinggi akan berpengaruh terhadap terjadinya overweight (Gharib dan Rasheed, 2011). Menurut Misnadiarly (2007) menyatakan bahwa remaja yang mengalami overweight akan menimbulkan dampak fisik dan psikologis. Overweight merupakan salah satu faktor risiko yang dapat menyebabkan penyakit degeneratif seperti penyakit kardiovaskuler, diabetes melitus, arthritis, penyakit kantong empedu, gangguan fungsi pernafasan dan berbagai gangguan kulit.

Status gizi yang terjadi pada remaja dapat dipengaruhi oleh beberapa faktor, yaitu faktor internal dan faktor eksternal. Pertama, faktor internal mencakup genetik, asupan makanan dan penyakit infeksi. Kedua, faktor eksternal status gizi remaja dapat dipengaruhi oleh sektor budaya.

Remaja yang kebugarannya menurun maka akan berdampak pada munculnya penyakit seperti kardiovaskuler, kencing manis, obesitas dan jantung. Remaja dikatakan memiliki status kebugaran, ekonomi, sosial, budaya dan pengetahuan gizi (Suhardjo, 2003).

Salah satu faktor yang mempengaruhi status gizi remaja adalah pengetahuan gizi. Pengetahuan tentang gizi akan berpengaruh terhadap sikap dan perilaku dalam pemilihan makanan. Pada masa ini dalam pemilihan makanan remaja dipengaruhi oleh selera dan keinginan yang cenderung pada pemilihan makanan yang tinggi kalori dan lemak sehingga dapat memicu pertumbuhan berat badan. Pada remaja yang memiliki 
pengetahuan yang baik maka akan lebih memperhatikan asupan makan yang seimbang sehingga status gizinya baik (Rosa, 2011).

Penelitan yang dilakukan Suryaputra et al (2012) di Surabaya menyatakan bahwa terdapat perbedaan yang bermakna antara pengetahuan gizi dengan kejadian non overweight mempunyai pengetahuan gizi yang cukup, sedangkan kelompok overweight mempunyai pengetahuan gizi yang kurang. Menurut Oktaviana (2008) terdapat hubungan yang signifikan antara tingkat pengetahuan gizi dengan status gizi remaja. Penelitian ini menunjukkan bahwa remaja yang memiliki tingkat pengetahuan gizi yang baik lebih banyak yang memiliki status gizi baik, sedangkan remaja dengan tingkat pengetahuan gizi yang kurang lebih banyak mengalami status gizi kurang dan gizi lebih.

Faktor lain yang mempengaruhi kebugaran jasmani yaitu status gizi. Kebugaran jasmani merupakan kemampuan seseorang dalam melakukan aktifitas sehari-hari tanpa merasakan lelah. Remaja yang mengalami overweight akan merasakan sesak nafas, badan terasa berat, sering sakit pada bagian pinggang, pinggul, paha dan lutut (Suharjana, 2004).

\section{METODE PENELETIAN}

Penelitian ini menggunakan penelitian observasional pendekatan cross sectional, dalam penelitian ini dilakukan survei terhadap pengetahuan gizi dan tingkat kebugaran jasmani yang overweight dan non overweight pada remaja, dimana pengambilan datanya di lakukan dalam waktu yang bersamaan.

Tempat penelitian dilakukan di SMK Batik 2 Surakarta dipilih berdasarkan lokasinya yang berdekatan dengan pusat perbelanjaan (mall) dan di sekitar sekolah banyak banyak menjual makanan cepat saji.

Populasi dalam penelitian ini adalah anak remaja di SMK Batik 2 Surakarta kelas X dan XI yang berjumlah 339 siswa.

Besar sampel penelitian ditentukan dengan populasi terbatas dengan rumus Lamesshow 1997 :

$\mathrm{N}=\frac{Z^{2}-\alpha / 2\left[P_{1}(1-P 1)+P 2(1-P 2)\right]}{d^{2}}$

Keterangan :

$\mathrm{N}=$ Besar sampel yang diperlukan

$\mathrm{Z}^{2}-\alpha / 2=$ nilai distribusi normal pada $(\alpha) 0,05: 1,96$

$\mathrm{d}=$ Presisi/derajat ketepatan $(0,2)$

P1 =Proporsi prevalensi overweight di Jawa Tengah 0,054

P2 = Proporsi prevalensi overweight studi pendahuluan 0,13

$\mathrm{d}=$ presisi yang ingin dicapai dinyatakan dalam desimal

Cara pengambilan sampel untuk masing-masing kelompok dihitung dengan menggunakan metode simpel random sampling, yaitu dengan cara mengundi semua populasi (siswa) kemudian mengacak nama responden dengan sistem undian.

\section{Pengumpulan Data}

1. Data Primer

a. Identitas responden : diperoleh dengan cara mengisi kuisioner yang dibagikan, meliputi nama, umur, alamat, kelas.

b. Pengetahuan gizi: diperoleh dari pengisian kuisioner tentang pengetahuan gizi.

c. Kebugaran jasmani : diperoleh dari tes naik turun bangku selama 5 
menit dengan kecepatan 30 langkah per menit.

d. Data antropometri : diperoleh dengan mengukur berat badan dan tinggi badan secara langsung menggunakan timbangan digital dengan skala tingkat ketelitian $0.01 \mathrm{~kg}$ dan microtoice dengan skala $0.1 \mathrm{~cm}$.

\section{Data Sekunder}

Data sekunder meliputi data sekolah SMK, jumlah siswa SMK dan gambaran umum yangdiperoleh dari wakil kepala sekolah.

\section{HASIL DAN PEMBAHASAN}

SMK Batik 2 Surakarta terletak di Kota Bengawan Tepatnya di Jl. Slamet Riyadi Kleco-Surakarta. Letak SMK Batik II Surakarta ini sangat strategis dan sangat menunjang kegiatan belajar mengajar, selain itu juga terletak di antara Kota Solo dan perbatasan Sukoharjo yang mudah dilalui.

SMK Batik II Surakarta memiliki 20 kelas, yang terdiri dari 6 kelas untuk kelas $\mathrm{X}$ berjumlah sebanyak 158 siswa, 6 kelas untuk kelas XI berjumlah 181 siswa dan 8 kelas untuk kelas XII berjumlah sebanyak 210 siswa, sehingga total keseluruhan siswa 549 siswa.

Tabel 1. Distribusi Jenis Kelamin

\begin{tabular}{ccccc}
\hline & \multicolumn{3}{c}{ Status Gizi } \\
\cline { 2 - 5 } Kategori & Overweight & \multicolumn{2}{c}{$\begin{array}{c}\text { Non } \\
\text { Jenis }\end{array}$} \\
\cline { 2 - 5 } Kelamin & $\mathrm{n}$ & $\%$ & $\mathrm{n}$ & $\%$ \\
\hline Laki-laki & 1 & 3 & 1 & 3 \\
Perempuan & 29 & 97 & 2 & 97 \\
& & & 9 & \\
Total & 30 & 100 & 3 & 100 \\
& & & 0 & \\
\hline
\end{tabular}

Berdasarkan Tabel 1 diketahui bahwa sebagian besar subjek yang berstatus gizi overweight dengan jenis kelamin perempuan yaitu sebanyak 97\%, sedangkan subjek dengan status gizi overweight dengan jenis kelamin laki-laki sebanyak $3 \%$.

Menurut Budiyanto (2010), wanita lebih beresiko overweight karena total lemak pada tubuh wanita lebih besar yaitu $30 \%$, sedangkan pada pria berkisar 20$25 \%$. Wanita mempunyai tempat-tempat penyimpanan khusus untuk penimbunan jaringan lemak, seperti yang terdapat pada daerah pantat (glutal), daerah dada dan bahu sehingga wanita lebih berisiko mengalami kegemukan.

Tabel 2. Distribusi Pengetahuan Gizi Berdasarkan Status Gizi

\begin{tabular}{ccccc}
\hline \multirow{2}{*}{$\begin{array}{c}\text { Pengetahuan } \\
\text { Gizi }\end{array}$} & \multicolumn{3}{c}{ Status Gizi } \\
\cline { 2 - 5 } & Overweight & \multicolumn{2}{c}{$\begin{array}{c}\text { Non } \\
\text { Overweight }\end{array}$} \\
\cline { 2 - 5 } & $\mathrm{n}$ & $\%$ & $\mathrm{n}$ & $\%$ \\
\hline Kurang & 10 & 34 & 9 & 30 \\
Cukup & 16 & 53 & 1 & 53 \\
& & & 6 & \\
Baik & 4 & 13 & 5 & 17 \\
Total & 30 & 100 & 3 & 100 \\
& & & 0 & \\
\hline
\end{tabular}

Berdasarkan Tabel 2 menunjukkan bahwa subjek yang overweight dan non overweight memiliki tingkat pengetahuan gizi yang cukup yaitu 53\%. Pengetahuan gizi merupakan salah satu faktor yang mempengaruhi status gizi pada remaja. Menurut Sukanto (2000), pengetahuan gizi juga dapat dipengaruhi oleh adanya faktor sosial budaya seperti tingkat pendapatan orang tua serta tingkat pendidikan yang akan mempengaruhi seseorang dalam pemilihan makanan untuk dikonsumsi.

Tabel 3. Distribusi Kebugaran Jasmani Berdasarkan Status Gizi

\begin{tabular}{|c|c|c|}
\hline \multirow[b]{2}{*}{$\begin{array}{c}\text { Kebugaran } \\
\text { Jasmani }\end{array}$} & \multicolumn{2}{|c|}{ Status Gizi } \\
\hline & Overweight & $\begin{array}{c}\text { Non } \\
\text { Overweight }\end{array}$ \\
\hline
\end{tabular}




\begin{tabular}{ccccc}
\hline & $\mathrm{N}$ & $\%$ & $\mathrm{~N}$ & $\%$ \\
\hline Kurang & 22 & 73 & 8 & 27 \\
Sedang & 2 & 7 & 4 & 13 \\
Cukup & 5 & 17 & 12 & 40 \\
Baik & 0 & 0 & 2 & 7 \\
Sangat & 1 & 3 & 4 & 13 \\
Baik & & & & \\
Total & 30 & 100 & 30 & 100 \\
\hline
\end{tabular}

Berdasarkan Tabel 3 terlihat bahwa kejadian overweight cenderung memiliki kebugaran jasmani yang kurang yaitu $73 \%$, sedangkan pada kejadian non overweight cenderung memiliki kebugaran jasmani yang cukup yaitu $40 \%$.

Remaja yang mengalami overweight akan merasakan sesak nafas, badan terasa berat, sering sakit pada bagian pinggang, pinggul, paha dan lutut, sehingga pada remaja yang overweight membutuhkan usaha yang lebih keras untuk melakukan kegiatan sehari-hari (Suharjana, 2004).

\section{Perbedaan Pengetahuan Gizi Antara Remaja Yang Overweight Dan Non Overweight}

Overweight tidak hanya dialami oleh remaja dengan pengetahuan gizi kurang, namun juga dialami remaja yang mempunyai pengetahua gizi baik. Perbedaan pengetahuan antara remaja yang overweight dan non overweight dapat dilihat pada tabel 4 .

Tabel 4. Rerata Pengetahuan Gizi Antara Remaja Overweight dan Non Overweight

\begin{tabular}{|c|c|c|c|}
\hline \multirow{2}{*}{$\begin{array}{l}\text { Pengetahuan } \\
\text { Gizi }\end{array}$} & \multicolumn{2}{|c|}{ Status Gizi } & \multirow[b]{2}{*}{$p$} \\
\hline & Overweight & $\begin{array}{c}\text { Non } \\
\text { Overweight }\end{array}$ & \\
\hline Mean & 65 & 66 & \multirow{6}{*}{0.750} \\
\hline Median & 67 & 69 & \\
\hline $\begin{array}{c}\text { Std. } \\
\text { Deviation } \\
\end{array}$ & 12 & 12 & \\
\hline Minimum & 38 & 35 & \\
\hline Maximum & 88 & 85 & \\
\hline Range & 50 & 50 & \\
\hline
\end{tabular}

Berdasarkan tabel 4 diketahui asil uji $t$ test independent menunjukkan nilai $p$ 0.750 yang berarti tidak terdapat perbedaan pengetahuan gizi antara remaja overweight dan non overweight di SMK Batik 2 Surakarta. Secara kuantitas nilai rerata pengetahuan gizi pada remaja nonoverweight lebih tinggi yaitu 66, sedangkan remaja yang overweight yaitu 65.

Tidak terdapatnya perbedaan pengetahuan gizi antara remaja overweight dan non overweight ini menunjukkan bahwa tingkat pengetahuan gizi tidak hanya dipengaruhi oleh status gizi tetapi dapat dipengaruhi oleh informasi yang sering didapatkan oleh subjek, baik dari media cetak maupun elektronik yang dapat menyebabkan remaja tidak memiliki sikap dan perilaku yang baik dalam pemilihan bahan makanan. Seperti yang dijelaskan oleh Nix (2005), bahwa pada umumnya kebiasaan makan remaja tidak dipengaruhi oleh zat-zat gizi yang terkandung dalam makanan melainkan berasal dari budaya kelompok yang diajarkan oleh anggota kelompok keluarga. Perubahan ini membuat seorang remaja mengalami banyak ragam gaya hidup, perilaku, tidak terkecuali pengalaman dalam menentukan makanan apa yang akan dikonsumsi (Proverawati, 2010).

\section{Perbedaan Kebugaran Jasmani Antara Remaja Yang Overweight Dan Non Overweight}

Perbedaan kebugaran jasmani antara remaja yang overweight dan non overweight dapat dilihat pada tabel 5. Berdasarkan hasil uji $t$ test independent diperoleh nilai $p<0.05$ yang berarti terdapat perbedaan yang bermakna kebugaran jasmani antara remaja 
overweight dan non overweight di SMK Batik 2 Surakarta.

Tabel 5. Rerata Kebugaran Jasmani Antara Remaja Putri Yang Overweight dan Non Overweight

\begin{tabular}{|c|c|c|c|}
\hline \multirow{2}{*}{$\begin{array}{c}\text { Kebugaran } \\
\text { Jasmani }\end{array}$} & \multicolumn{2}{|c|}{ Status Gizi } & \multirow[b]{2}{*}{$p$} \\
\hline & Overweight & $\begin{array}{c}\text { Non } \\
\text { Overweight }\end{array}$ & \\
\hline Mean & 49 & 68 & \\
\hline Median & 46 & 73 & \\
\hline $\begin{array}{c}\text { Std. } \\
\text { Deviation }\end{array}$ & 13 & 19 & 0.00 \\
\hline Minimum & 32 & 34 & \\
\hline Maximum & 78 & 104 & \\
\hline Range & 47 & 70 & \\
\hline
\end{tabular}

Secara kuantitas nilai rerata kebugaran jasmani pada remaja overweight memiliki kebugaran jasmani yang kurang sekali yaitu 49, sedangkan pada remaja yang non overweight memiliki kebugaran jasmani yang sedang yaitu 67.

Remaja yang mengalami overweight akan menyebabkan rendahnya daya kardiorespiratori yang menghantarkan oksigen ke sel tubuh, sehingga dalam melakukan kegiatan sehari-sehari akan cepat merasa kelelahan. Menurut Irianto (2004), salah satu komponen kebugaran jasmani yaitu daya tahan kardiorespirasi yang berfungsi secara optimal saat melakukan kegiatan sehari-hari tanpa merasakan kelelahan.

Berdasarkan Peterson (2004), menyatakan bahwa remaja yang overweight akan berpengaruh terhadap berat tulang, otot dan lemak, sehingga pada remaja yang overweight membutuhkan usaha yang lebih keras untuk melakukan kegiatan sehari-hari. Sebagian besar subjek cenderung menyukai makanan olahan yang siap saji seperti fast food di banding makan makanan di rumah. Penelitian ini sejalan dengan Susilowati (2007), yang menyatakan bahwa terdapat hubungan antara kebugaran jasmani dengan status gizi. Penelitian lain yang dilakukan oleh Pribis (2010) juga melaporkan hal yang sama yang menyatakan bahwa ada hubungan antara kebugaran jasmani dengan status gizi.

\section{KESIMPULAN}

1. Remaja di SMK Batik II Surakarta yang overweightdan non overweightmempunyai pengetahuan gizi kategori cukup sebanyak 53\%.

2. Sebanyak $73 \%$ remaja yang overweight di SMK Batik II Surakarta mempunyai kebugaran jasmani yang kurang.

3. Tidak terdapat perbedaan pengetahuan gizi antara remaja yang overweight dan non overweight di SMK Batik II Surakarta. Sebagian besar remaja yang overweight dan non overweight memiliki pengetahuan gizi yang cukup.

4. Terdapat perbedaan kebugaran jasmani antara remaja yang overweight dan non overweight di SMK Batik II Surakarta. Sebagian besar remaja overweight mempunyai kebugaran jasmani yang kurang dibandingkan dengan yang non overweight.

\section{DAFTAR PUSTAKA}

Almatsier., 2011, Gizi Seimbang Dalam Daur Kehidupan, PT Gramedia Pustaka Utama, Jakarta.

Budiyanto, Moch. A. K., 2010, Dasar-Dasar Ilmu Gizi, Malang, UMM PRESS. 
Gharib, N dan Rasheed., 2011, Energi and Macronutrient Intake and Dietary Pattern Among School Children in Bahrain, Dammam University, Saudi arabia.

Irianto, Kus., 2004, Gizi dan Pola Hidup Sehat, Yrama Widya, Bandung.

Misnadiarly., 2007, Obesitas dan Berbagai Faktor Risiko Beberapa Penyakit, Pustaka Obor Populer, Jakarta.

Nix. S., 2005, William's Basic Nutrition \& Diet Theraphy, 12th Edition, Elsevier Mosby Inc, USA.

Oktaviana., 2008, Hubungan Keaktifan Keluarga dalam Kegiatan Posyandu dengan Status Gizi Balita di Desa Rancaekek Kulon Kecamatan Rancaekek, UNPAD.

Peterson, C., 2004, Character Srengths and Virtues: a handbook of classification, Oxford University Press, Washington DC: Amerika Psychological Association/NewYork.

Pribis, P., 2010, Trend In Body Fat, Body mass Index And Physical Fitness Among Male And Female College Student, Nutriens.

Proverawati, A., 2010, Obesitas dan Gangguan Perilaku Makan, Nuha Medika, Yogyakarta.

Riset Kesehatan Dasar (Riskesdas)., 2013, Pedoman Pewawancara Petugas Pengumpul Data, Badan Litbangkes, Depkes RI, Jakarta.

Rosa., 2011, Pengetahuan Gizi Dan Keamanan Pangan Jajanan Serta Kebiasaan Jajan Siswa Sekolah Dasar Di Depok dan Sukabumi

Suharjana., 2004, Kebugaran Jasmani, Buku Pegangan Kuliah Mahsiswa FIK UNY, FIK UNY, Yogyakarta.

Suhardjo., 2003, Berbagai Cara Pendidikan Gizi, Bumi Aksara, Jakarta.

Sukanto., 2000, Organisasi Perusahaan, Teori Struktur dan Perilaku, Badan Penerbitan Fakultas Ekonomi Universitas Gajah Mada, Yogyakarta

Suryaputra, K., Rahayu, S., 2012, Perbedaan Pola Makan dan Aktivitas Fisik Antara Remaja Obesitas Dengan Non Obesitas, Makara Kesehatan

Susilowati., 2007, Fakto-Faktor Risiko Kesegaran Jasmani, Program Pasca Sarjana, Universitas Diponegoro, Semarang 
JURNAL KESEHATAN, ISSN 1979-7621, Vol. 1, No. 2, Desember 2016 